\title{
Horizonte nebuloso
}

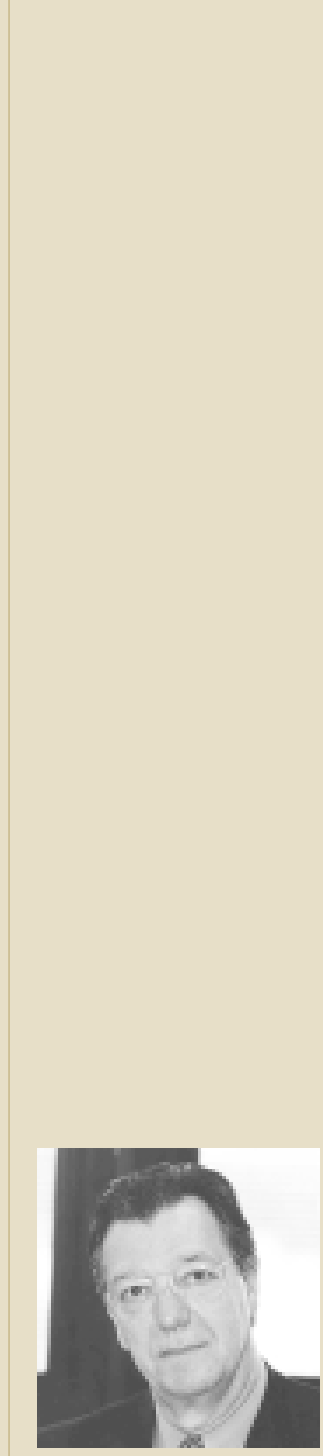

Carlos Osmar Bertero FGV-EAESP

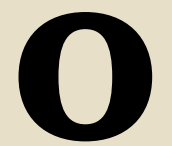

final do ano marca, para as empresas, a conhecida temporada "decaça ao planejamento estratégico". N ossos valorosos líderes corporativos saem a campo em busca do tempo perdido. Nesse ritual pré natalino, discutem-se o ambiente e a conjuntura - bases sobre as quais a estratégia será ancorada.

Ambiente e conjuntura são conceitos presentes em quase todos os model os de formulação e revisão de estratégia. Mas este ano a propalada temporada de caça promete emoções especiais. Os estrategistas devem considerar que o país não atravessa uma boa fase e que as perspectivas de que venha a superá-la são remotas. Indicadores macroeconômicos mostram que a renda per capita tem crescido muito lentamente desde o início dos anos 1980. As repercussões da "estagnação" sobre os níveis de renda e consumo são inevitáveis. Os candidatos à presidência acenavam com possibilidades de retomada, mas as promessas resistem ao teste da realidade?

0 país enfrenta quatro obstáculos que impedem a retomada de um crescimento econômico sustentado.

Em primeiro lugar, temos o problema das contas públicas e seus corolários, como o endividamento interno e o ônus sobre o setor privado. 0 desequilíbrio das contas internas e os conseqüentes aumentos desse endividamento e de carga tributária indicam que as despesas públicas continuam aumentando mais rapidamente que as receitas. Depois, temos uma balança comercial precariamente equilibrada, com pequenos déficits ou superávites e um monumental rombo no balanço de serviços - o que converge para um desequilíbrio constante nas contas externas. Esse contexto nos levou ao FMI por três vezes nos últimos oito anos. Em terceiro lugar, temos de reconhecer nossa combalida infra-estrutura. Nada indica que o Estado tenha condições de retomar seu papel de provedor de infraestrutura, exercido até o início da década de 1980.

Por fim, há o déficit educacional e tecnológico. Em relatórios internacionais abundam indicadores de nossa terrível performance nessa área. A educação não mereceu prioridadeao longo do século XX. Mesmo nossas mais reputadas instituições ficam a dever a congêneres estrangeiras. Enquanto isso, o déficit tecnológico tende a perpetuar nossa dependência com relação às economias mais avançadas.

Para as empresas, ainda que pese a sedução dos discursos voluntaristas, há poucas chances de vingarem estratégias de crescimento. É possível que al gumas empresas prosperem no caos e na estagnação, mas a maioria certamente enfrentará dificuldades. 0 que se pode recomendar é muito pouco: a hora é de prudência e de busca de fundamentos consistentes na gestão dos negócios. No mais, mesmo em situações difíceis como a que se avizinha, doses generosas de criatividade e inovação são sempre bem-vindas. 